\title{
Consumer Behavior Analysis in Choosing Conventional or Sharia Mortgage Product in Indonesia
}

\author{
Mochamad Reza Adiyanto ${ }^{1}$, Ujang Sumarwan ${ }^{2}$, Imam Teguh Saptono ${ }^{3}$ \\ ${ }^{1}$ Graduate Student of Master Program Management School of Business, Bogor Agricultural University \\ ${ }^{2}$ Department of Family and Consumer Sciences and School of Business Bogor Agricultural University \\ ${ }^{3}$ Faculty Member School of Business, Bogor Agricultural University \\ Correspondence: Mochamad Reza Adiyanto. E-mail: mochrezaadiyanto@gmail.com
}

Received: May 3, 2017

doi:10.5539/ass.v13n8p74
Accepted: May 24, 2017 Online Published: July 25, 2017

URL: https://doi.org/10.5539/ass.v13n8p74

\begin{abstract}
The objectives of this study are 1) Analyze sharia mortgage market segment based on demographic and psychographic, 2) Analyze the factors that influence the type selection of sharia mortgage, 3) Formulate the managerial implications to increase market share sharia mortgage. This study used two approaches, the first approach is to use AIO (Attitude, Interest, Opinions) psychographic factors to measure consumer lifestyles before mapped into multiple segments. The second approach is to use the planned behavior theory (TPB). TPB is used to find out the factors that influence consumer in making decisions to purchase sharia mortgages. The data used is primary data that is quantitative. The primary data was obtained from questionnaires by consumers who will buy a house through mortgage facilities. The sample is determined intentionally (convenience sampling). The respondents are 150 people. The results showed that consumers are going to buy a house through mortgage facilities divided into 3 clusters. The first cluster is respondents who chose a sharia mortgage have monotonous, introvert, conservative and conformist personalities. The second cluster are respondents who chose conventional mortgages and have dynamic, extrovert, risk-taker and rationalist personalities. Meanwhile, the third cluster is respondents who chose conventional and sharia mortgages simultaneously and have dynamic, extrovert, risk-taker and universalist personalities. Based on the multiple regression analysis it shows that the output evaluation factor $\left(\mathrm{X}_{2}\right)$ significantly affects the respondents' interest in proposing a sharia mortgage, while the trust behavior factor $\left(\mathrm{X}_{1}\right)$, the trust control $\left(\mathrm{X}_{3}\right)$, the motivation $\left(\mathrm{X}_{4}\right)$, the trust control $\left(\mathrm{X}_{5}\right)$, power factor control $\left(\mathrm{X}_{6}\right)$ have no significant effect. This study implies that sharia bank management should focus on $3^{\text {rd }}$ clusters because it has a big potential market through generic strategies, market challenge strategies and marketing mix strategies.
\end{abstract}

Keywords: mortgage, conventional, sharia, rationalist, conformist, and universalist

\section{Introduction}

\subsection{Background}

East Java province has much potential as the second largest population and the highest economic growth above the national average (Kemendagri, 2015). However, the East Java region has been impacted by the current conditions in Indonesia. The economic growth in 2015, only grew by 5.44 percent, or lower than 2014, which amounted to 5.86 percent (BPS, 2016). Such conditions have an impact on the decrease of bank lending from $9 \%$ in 2015, to 2\% from the June period in 2016 (Otorita Jasa Keuangan, 2016).

In order to cope with these conditions, the OJK (Otorita Jasa Keuangan) and BI (Bank Indonesia) issued a regulation focusing on boosting the demand side, such as: decreasing interest rates on loans, decreasing the DP (Down Payment) minimum, or advancing payments for consumers who will buy a house through a credit facility / finance property (Bank Indonesia, 2015).

The sharia mortgage has a small market share, especially in East Java. That is a problem for the Sharia finance industry. Based on data from the OJK in June 2016 period, only 16\% of the total outstanding mortgages were distributed by conventional and sharia banking (Otorita Jasa Keuangan, 2016). This impacts the existing market potential as the percentage of the Muslim population in East Java is $96.36 \%$ based on the data census population BPS 2010 (Badan Pusat Statistik, 2016). 
This was caused by the unfavorable external conditions and internal conditions of the banking industry with increasingly tighter competition intensity, and banks are required to apply marketing strategies in order to influence consumer behavior so that they are interested in making purchasing decisions on the products offered.

In terms of the internal side of banking, Marwa et al. (2014) determined the effect of the mixed marketing in the consumers' decision, and it is known that the product variable is the most influence variable in consumer purchasing decisions. Thus banks need to create a competitive product so that consumers can be interested in buying it.

Viewed from the external side, the consumer, Sumarwan (2015) conducted an analysis of factors that influence credit card ownership. The result from the study shows that consumer income was influenced significantly in the consumer's decision to choose a credit card. In addition, Sari (2015) claimed that religious factors were not the only primary reasons related to sharia banking so that the study showed that individual consumer factors, and social and culture all influence the consumer's decision to use a sharia bank product.

Based on the matter above, the sharia banking management requires effective marketing strategies in order to increase its share of the mortgage market in East Java. So, this study attempts to identify segment sharia property viewed by demographic and psychographic factors through lifestyle and personality approaches. In addition, to determine factors that influence consumers to choose sharia mortgage facilities, to formulate the managerial implications toward consumer behavior financing sharia mortgage and to understand the increase in the market share of the financing sharia property.

\section{Literature Review}

\subsection{Theory of Planned Behavior (TPB) Research in Choosing Mortgage Product}

Sumarwan (2011) stated that the theory of planned behavior (TPB) is a model that estimates the attitude of consumer's interest or the intention to perform a behavior or action. According to Ajzen (2005), the theory of planned behavior is a theory that is used to predict the behavior of individuals based on factors of attitude toward their behavior, subjective norms and behavioral control. Fishbein and Ajzen in Blue (1995) stated that intention to behave is the single best predictor of a person's behavior (behavior). Behavioral intention is a function of attitudes towards behavior (attitude toward behavior) and subjective norms (subjective norm). Sumarwan (2011) stated that the intention to behave will be influenced by the attitude toward the behavior (attitude toward behavior) and subjective norms (subjective norm about behavior). Sayono et al. (2009) expressed that the intention to apply for credit (intention to apply for credit) is the person's behavior tendency to take decisions in applying for credit because of interest (interest) and desire (desire) that comes from internal or external persuasive stimulus against the credit offered.

Lestari et al. (2017) concluded that the respondents interest in credit card ownership is still very low. This shows from the study findings that only $17 \%$ of respondents expressed interest in the credit card. The main factors that affect the interest of respondents to credit card ownership is perceived as behavioral control so the banks are expected to educate and motivate consumers to change the public mindset or address the negative public perception about credit cards so that the credit card is widely accepted and used as a non-cash form of payment. Ringim (2013) in his study 'Nigerian Muslims Public Perception Who Have Conventional Bank Account against Sharia Bank Product' concluded that the respondents' perception about service quality Sharia Bank is satisfying so that Sharia banks are required to constantly improve service quality, image and reputation to gain the maximum customer satisfaction. Kennedy (2013) in his study 'Theory of Planned Behavior and Financial Literacy: Prediction Model for Credit Card Debt' concluded that consumer attitudes toward credit card debt and behavioral control perception significantly influence the intention of using a credit card. The study showed that individual beliefs related to the attitudes toward using credit cards. Amin et al. (2013) in his study 'Muslim Consumer Behavior Theory: Empirical Study of Consumer Behavior Malaysia Islamic mortgage' concluded that the level of education and the level of religiosity are tools to determine the preferences of a sharia mortgage. Instead, fairness and friendliness are not significantly related to the preference for a sharia mortgage.

Based on Amin (2013), it was stated that the study about consumer behavior in choosing the sharia mortgage is important because it contributes to the empirical framework development of sharia finance in predicting the consumer behavior within the Sharia mortgage market. Meanwhile, according to Ringim (2013), the study about the public perception of Sharia banks is needed to improve public knowledge about the sharia bank's characteristics and improve the public interest doing financial transactions through sharia banks. Moreover, Amin (2014) in his study 'Consumers' Acceptance regarding sharia mortgage' emphasizes the importance of this study to predict the demand of sharia mortgage in the future. 
Conclusions can be made by the study about the factors influence in choosing credit card through theory planned behavior (Theory planned behavior) TPB, another approach is knowing the perceived behavioral control (PBC) variables: the perceived behavioral control influences the interest credit card ownership in Indonesia (Lestari, et al., 2008). On the contrary, Attitude toward Behavior (ATB) variables: subjective norms can determine how consumers choose sharia mortgage products in Malaysia (Amien et al, 2014).

Ismail et al. (2014) proposed that the banks' reputation variables play a critical role in determining the Muslims and the non-Muslims consumer decisions as compared to choosing a sharia mortgage in Malaysia. A good image and reputation makes consumers confident to choose sharia mortgages. In addition, a level of religiosity and educational level variables determine the preferences to choose sharia mortgage (Amin et al., 2013). According to Ringim (2013) that service quality variable affects the individuals' perception to buy products and services of sharia banking in Nigeria.

There are similarities between these studies with the previous study. The similarities can be seen from the objectives and the study approach used to determine the factors that influence the consumers' decision to apply for credit / financing by using the theory of planned behavior (Theory of Planned Behavior) TPB approach as in the study conducted by religiosity Amin et al. (2014), Lestari et al. (2008) and Kennedy (2013).

There are differences between these studies and the previous study. The difference can be seen from an analysis tool used to determine the factors that influence consumers to choose a Sharia mortgage product and the objective studied especially in the study conducted by Ringim (2013), Bieber et al. (2017), Kennedy (2013).

\subsection{Consumer Behavior Study in Choosing Mortgage Product}

Sumarwan et al. (2012) conducted a study of the influence of perceptions and ads preferences on children's purchase intentions for snack food products. The study uses an experimental factorial design with two variables, that is the first treatments: advertising exposure followed by a consumer test, the second treatment: consumer test followed by an advertising exposure with both males and females. The results showed that the variables that affect the children's purchase intention of snack food products are perceptions, and preferences and experiences of consuming the product. The gender variables and gender interactions also influence significantly the formation of children's perception of the advertisement snacks.

Pratama et al. (2016) found in the study that the analysis of factors that affect buyers advertising avoidance (the difference in the numbers of viewers who watched ads with viewers who watched the program) are the demographics audience (gender, age, residential areas, and socio-economic status), the ad attributes (television, advertising sequence, program genre, and the advertising sector), and competition (Day part). This study tried to measure the level of advertising avoidance in Indonesia and its relationship to various factors that pose an influence by using secondary data. The results showed that the level of advertising avoidance in Indonesia is $23 \%$; such relatively similar to other studies in various countries. Hypothesis test results also showed the significance of advertising avoidance relationship with demographic variables, the ad attributes, and the competition that influences it.

Siahaan et al. (2015) conducted a study of factors that affect the intention of local soy sauce users. The study used the approach of planned behavior (Theory of planned behavior) and who is purchase intention as a key driver for the occurrence of a particular behavior. The results showed that attitudes toward behavior (Aact) and perceived behavioral control (PBC) is a significant component that affects the intention of local soy sauce users, while the components of subjective norm (SN) does not affect the results significantly. Based on the study results, the factors that affect the intention of local soy sauce users are profit, making the savory dishes, bringing prosperity to the local community, affordable prices, good quality, and convenience.

Nugroho et al. (2015) conducted a study to analyze the factors that influence purchasing decisions and organic tofu consumption. The study divides the consumers into three groups: (a) consumers who have never bought but interested to buy, (b) consumers who have never purchased but not interested to buy, and (c) consumers who have never purchased organic tofu. The results showed the characteristics of respondents who have never purchased were mostly in the 26-35 age group, college educated, umemployed, has an income of between 1 million up to 2.5 million, has a wide knowledge, has a perception that the highest score in organic farming sustainability, is environmental friendly, has health benefits and has higher prices. These are the factors that influence consumers in making purchasing decisions to buy organic tofu are work and knowledge.

Sayono et al. (2009) conducted study on the factors that influence the decision of credit card ownership in Jakarta. The study analyzed the demographic factors, motivational factors, attitudes and personality factors related to risks and innovations of credit cards. The results showed that demographic factors and motivational 
factors significantly influence consumer decisions.

There are differences and similarities between these studies and with previous studies. The similarities can be seen from the purpose of the study and the analysis methods which were used to determine the factors that influence consumer purchasing decisions; such by using multiple linear regression analysis. In addition, there are also differences, especially on the object studied, Sumarwan et al. (2012) conducted a study on children, Pratama et al. (2016) conducted a study on the television viewers, Siahaan et al. (2015) and Nugroho et al. (2015) conducted a study on consumer organic soy or tofu, and Sayono et al. (2009) conducted a study on the objective of credit card consumers.

\subsection{Mortgage Consumer Segmentation Study}

Sanjaya et al. (2015) in the study of the relationship analysis among customer relationship management (CRM) maintained that it is measured by the perception of customer through the level of customers' loyalty. The study uses recency, frequency and monetary (RFM) to measure loyalty and CRM through people, process and technology. Based on RFM segmentation it produced five segments, they are platinum segments, gold segments, silver segments, blue segments and black segments. The study mapped that the majority of customer' savings SiAga cooperation XYZ contained in the Silver segment (57\%) with a high recentcy level; while the frequency and monetary aspects tended to be low, whereas for customers with high RFM level (platinum segment) was only $12 \%$.

Djamaludin et al. (2009) in the study analysis of Jamu Gendong customer satisfaction and loyalty in Sukabumi in which one of purposes was to analyze the Jamu Gendong customer. The results showed that there are five types of buyers: the switcher / price buyers are consumers who frequently switch between one type/brand to other type/brand products, Habitual buyer is the Jamu Gendong consumer who buys Jamu Gendong based on their habit, the satisfied buyer is the consumer who is satisfied when making the purchase of a product, the likes the brand consumer is truly a consumer who really likes Jamu Gendong and the committed buyer is a loyal consumer who buys Jamu Gendong.

Based on Amalia et al. (2011), Alboneh et al. (2010), Irviana et al. (2008), Wijaya et al. (2006), studies claimed that the segmentation of the Sharia Bank market consumer is based on behavioral variables divided into three groups: Sharia loyalist (a market segment who choose and loyal to the sharia bank for consideration halal and haram), floating more sharia and floating less sharia means a floating segment which more considers the advantages and conveniences of services to choose sharia banks or conventional banks. Meanwhile, when attention is further directed into the mortgage consumer segmentation based on psychographic variables, Ambiatini et al. (2005) divides them into two segments, they are the segment that has the characteristics of a dynamic lifestyle and the segment that has the characteristics of a static lifestyle. Each individual study explanation is as follows:

The study conducted by Ambiatini et al. (2005) aimed to: 1) Analyze mortgage customer segmentation at Bank $X, 2)$ to analyze the attributed priority mortgage products for customers mortgage Bank $X, 3$ ) Provide recommendations for mortgage marketing strategies which can be enacted at Bank X. The scope this study is limited to Bank X customers and Bank X mortgage customers, with a case study in the branch office in Jakarta. The study was conducted by using survey methods to 120 respondents with convenience sampling technique. The primary data was obtained from questionnaires and direct interviews with respondents. The questions posed to customers included an assessment of the mortgage attribute consisting of: interest rates, credit terms, credit periods, down payment, the cost of the process, the credit process, the maximum credit, marketing information, banking halls and bank locations. The analysis tools used are: (1) Cluster analysis used for customer segmentation based on psychographic and demographic characteristics aspects, (2) Thurstone analysis, which is used to determine the attributed priority, and (3) Analysis of PA matrix to describe the performance compared to customer expectations against Bank X mortgage attributed product.

The results of a study conducted by Ambiatini et al. (2005) pertains to the formation of two segments; namely, A and B segments. A segment is a group of customers who have a dynamic lifestyle, are creative, have lots of activities, are fair, have great optimism and have good planning. This group is dominated by men who have relatively a small number of members within the family; they are generally private employees, the average earnings are over $\$ 4$ million per month, and are scholars. While the B segment is a group of customers that is neutral, static although they have a hope to go forward, and are quite conducive to a family environment. These groups are generally customers who have a family with a large number of members of up to 9 people, mostly civil servants, and with an average income of between Rp 2 million and up to Rp 4 million a month. Mortgage attributes that are considered which are important for customers and have a low performance are the interest rate, 
credit terms, the credit process and the cost of the process. A segment assessment found that the four attributes are: interest rates, the rapidity of credit, credit terms and cost of the process; such were assessed as having a high importance level but have a low performance. Whereas, B Segment considers that there are five attributes that have importance high level but cannot comply with customer expectations, they are: credit interest rates, credit terms, low down payment, low cost and the rapidity of credit processes.

Furthermore, the similar previous studies are conducted by Yudha (2011), which aimed to identify the segment of the market of Mandiri mortgages in Denpasar based on the benefits of demographics and behavior, define a segment that is prioritized as a target market Mandiri mortgage in Denpasar, and determine positioning of the Mandiri mortgage product at Denpasar, and also the implications for the next marketing strategy. In realizing the goal of this study, it conducted the analysis of segmenting, targeting and positioning using cluster analysis to determine the market segments, market targets, and multi dimensional scaling and correspondence analysis to determine the position of the product. The population of this study was 7000 customers using a Mandiri mortgage and the study used a sampled 230 respondents by purposive sampling technique. The results showed that all Mandiri mortgage customers can be grouped into three segments. The three segments are formed based on the benefits of the demographics of consumer behavior, they are Segment 1 which provides a positive value towards an officer's responsive, security benefits, factors of empathy, factors of direct evidence and economics. Segment 2 gives a positive value to the reliability service factor, officers responsive, assurance benefits, empathy factor and economic factors. Segment 3 provides a positive assessment towards the factors assurance, empathy factor, and economic factors. Based on the three clusters above, the most suitable cluster used as a market target is the cluster 1. This is concluded with two kinds of considerations, and they are based on benefits, demographics and behavior. Positioning showed that the Mandiri mortgage competes with BNI mortgages because they are in one quadrant mutual advantages in the form of attribute knowledge officer, penalty, and credit terms. This is different from other mortgage bank products, which do not have similar attributes because the Mandiri mortgage has a different quadrant from Permata mortgages and BTN mortgages.

There are the differences and similarities between these studies with the previous study. The similarities can be seen from the objective of the study which is about consumers who will buy a house through mortgage facilities (mortgage) as the studies conducted by Amalia et al. (2011), Alboneh et al. (2010), Irviana et al. (2008), Wijaya et al. (2006), Ambiatini et al. (2005) and Yudha (2011), conducted studies about market segmentation mortgage bank consumers. However, there are also the differences with the previous study especially with Sanjaya et al. (2015) and Djamaludin et al. (2009) studies which conducted consumer loyalty studies.

\section{Methods}

\subsection{Research Location and Time}

The location of this study was conducted in 15 (fifteen) housing developer projects located in East Java region, especially in Surabaya, Sidoarjo and Gresik. This study was conducted from December 2016 to January 2017.

\subsection{Research Design}

This study uses a survey approach because the research concerns the behavior of people, work processes, natural phenomena, and the number of observed respondents are not too large. In this study, the phenomenon under investigation is the market segmentation of conventional property credit and sharia mortgage with the personality, lifestyle demographic and psychographic approach and also the differentiating factor in which consumers make decisions to choose financing sharia mortgage facilities compared with conventional property credit.

\subsection{Data Collection Method}

Data collection would be carried out through surveys to respondents using online questionnaires to consumers who make purchases property in Surabaya, Sidoarjo and Gresik. The questionnaire consists of questions that are formulated to make the respondent record the answer usually to closed questions, and alternative answers have also been determined. The questionnaire contains questions that should be answered by the respondents with the answer choices which have been pre-determined.

\subsection{Research Objective}

The objective of this study pertains to the consumers who will buy a property (residence, shop, home office or parcel of land) in East Java, especially in Surabaya, Sidoarjo and Gresik. The respondents in this study are family members who may come to the developer marketing office and who may be looking for information about the property for sale. 


\subsection{Definition of Study Variable}

To facilitate the respondents' answers to the questionnaires, they are given directions and instructions. The operational definition in this study includes:

\subsubsection{Demographic Variable}

It is the market's division/separation based on the composition of the consumer (age, family size, gender, income, occupation, education, religion and marital status) who will acquire properties using a conventional credit facility property or finance sharia property.

Table 1. Indicators and measurement scale demographic variables

\begin{tabular}{|c|c|c|c|c|c|}
\hline Variable & Variable description & Dimension & Indicator & Questionnaire grating & $\begin{array}{c}\text { Measurem } \\
\text { ent scale }\end{array}$ \\
\hline \multirow{9}{*}{ Demography } & \multirow[t]{9}{*}{$\begin{array}{c}\text { Grouping based of } \\
\text { socioeconomic variables, } \\
\text { such as gender, education, } \\
\text { age, family size, } \\
\text { occupation, religion. }\end{array}$} & Age & $\begin{array}{l}\text { Recently respondent } \\
\text { age }\end{array}$ & $\begin{array}{l}\text { a. } \leq 30 \text { years } \\
\text { b. } 31-35 \text { years } \\
\text { c. } 36-40 \text { years } \\
\text { d. } 41-45 \text { years } \\
\text { e. } \geq 46 \text { years }\end{array}$ & $\begin{array}{l}\text { Nominal } \\
\text { scale }\end{array}$ \\
\hline & & Family size & $\begin{array}{l}\text { Total members in } \\
\text { family }\end{array}$ & $\begin{array}{l}\text { a. } \quad 1-2 \text { people } \\
\text { b. } 3-4 \text { people } \\
\text { c. } 5-6 \text { people } \\
\text { d. } \geq 7 \text { people }\end{array}$ & $\begin{array}{l}\text { Nominal } \\
\text { scale }\end{array}$ \\
\hline & & Gender & Respondents' gender & $\begin{array}{ll}\text { a. } & \text { Male } \\
\text { b. } & \text { Female } \\
\text { a. } & \leq \mathrm{Rp} 5 \text { million }\end{array}$ & $\begin{array}{l}\text { Nominal } \\
\text { scale }\end{array}$ \\
\hline & & Income & $\begin{array}{l}\text { Average income per } \\
\text { month }\end{array}$ & $\begin{array}{l}\text { b. } \quad \text { Rp } 6 \text { million - Rp } 10 \text { million } \\
\text { c. } \quad \operatorname{Rp} 11 \text { million }- \text { Rp } 15 \text { million } \\
\text { d. } \quad \geq \operatorname{Rp} 16 \text { million }\end{array}$ & \\
\hline & & Occupation & $\begin{array}{l}\text { Respondents' } \\
\text { occupation }\end{array}$ & $\begin{array}{ll}\text { a. } & \text { Civil servant } \\
\text { b. } & \text { Private employee } \\
\text { c. } & \text { Entrepreneur } \\
\text { d. } & \text { Others }\end{array}$ & $\begin{array}{l}\text { Nominal } \\
\text { scale }\end{array}$ \\
\hline & & & & $\begin{array}{l}\text { a. High School } \\
\text { b. Diploma }\end{array}$ & \\
\hline & & Education & $\begin{array}{l}\text { Last respondents' } \\
\text { education }\end{array}$ & $\begin{array}{ll}\text { c. } & \text { S1 } \\
\text { d. } & \text { S2 } \\
\text { e. } & \text { S3 } \\
\text { f. } & \text { Others }\end{array}$ & $\begin{array}{l}\text { Nominal } \\
\text { scale }\end{array}$ \\
\hline & & Religion & $\begin{array}{l}\text { Respondents' } \\
\text { religion belief }\end{array}$ & $\begin{array}{ll}\text { a. } & \text { Moslem } \\
\text { b. } & \text { Catholic } \\
\text { c. } & \text { Protestant } \\
\text { d. } & \text { Hindu } \\
\text { e. } & \text { Buddha } \\
\text { f. } & \text { Konghucu } \\
\text { g. } & \text { Others }\end{array}$ & $\begin{array}{c}\text { Scale } \\
\text { nominal }\end{array}$ \\
\hline & & Marital status & $\begin{array}{l}\text { Recently marital } \\
\text { status }\end{array}$ & $\begin{array}{ll}\text { a. } & \text { Married } \\
\text { b. Single } \\
\text { c. } & \text { Widow/widower } \\
\end{array}$ & $\begin{array}{c}\text { Scale } \\
\text { nominal }\end{array}$ \\
\hline
\end{tabular}

\subsubsection{Psychographic variable}

\subsubsection{Lifestyle}

It is a market's division/separation based on respondents' statements about their activity (activity), interest (interest) and opinion (opinion) in allocating money and time to buy a property through a conventional credit property facility or finance sharia property.

Table 2. Indicator and psychographic lifestyle measurement scale variable

\begin{tabular}{|c|c|c|c|c|c|}
\hline Variable & Variable description & Dimension & Indicator & Parameter & $\begin{array}{c}\text { Measurement } \\
\text { scale }\end{array}$ \\
\hline Lifestyle & A pattern where people used to & Activity & Occupation & - Dinamic & Interval scale \\
\hline
\end{tabular}


live and spend their money and time

\section{- Monoton}

\begin{tabular}{|c|c|c|c|}
\hline & Applicative & $\begin{array}{l}\text { - Practical } \\
\text { - Detail }\end{array}$ & \\
\hline & Society & $\begin{array}{ll}\text { - } & \text { Ekstrovet (broad) } \\
\text { - Introvet (limited) }\end{array}$ & \\
\hline & Responsibility & $\begin{array}{l}\text { - Decision maker } \\
\text { - Follower }\end{array}$ & \\
\hline \multirow[t]{2}{*}{$\begin{array}{l}\text { Interest/ } \\
\text { Interest }\end{array}$} & Attention & $\begin{array}{l}\text { - Public attention } \\
\text { - Shy }\end{array}$ & Interval scale \\
\hline & Decision maker & $\begin{array}{l}\text { - Risk taker } \\
\text { - Conservative }\end{array}$ & \\
\hline \multirow[t]{2}{*}{$\begin{array}{l}\text { Opinion/ } \\
\text { Opinion }\end{array}$} & House & $\begin{array}{l}\text { - Luxury } \\
\text { - Medium }\end{array}$ & Interval scale \\
\hline & $\begin{array}{l}\text { Willingness to purchase } \\
\text { credit/ financing at bank }\end{array}$ & $\begin{array}{l}\text { - Simple } \\
\text { - No problem } \\
\text { - Reluctant to take } \\
\text { credit/financing at bank }\end{array}$ & \\
\hline
\end{tabular}

\subsubsection{Personality}

It is a market's division/separation based on respondents' statements about psychological characteristics which impact the selection of a conventional mortgage facility or a sharia mortgage when buying a property.

Table 3. Indicator and personality psychographic measurement scale variable

\begin{tabular}{|c|c|c|c|c|c|}
\hline Variable & Variable description & Dimension & Indicator & Questionnaires grating & $\begin{array}{c}\text { Measurem } \\
\text { ent scale }\end{array}$ \\
\hline \multirow[t]{3}{*}{ Personality } & $\begin{array}{l}\text { A set of human psychological } \\
\text { personality that affects to the } \\
\text { relatively consistent response } \\
\text { and more resistant to the } \\
\text { environmental stimulus }\end{array}$ & $\begin{array}{l}\text { Value } \\
\text { proportion }\end{array}$ & $\begin{array}{l}\text { Main } \\
\text { considerati } \\
\text { on in } \\
\text { buying } \\
\text { property }\end{array}$ & $\begin{array}{l}\text { a. lowest price } \\
\text { b. according to the needs } \\
\text { c. Property in accordance with religious value } \\
\text { d. according to the needs and religious values }\end{array}$ & $\begin{array}{l}\text { Interval } \\
\text { scale }\end{array}$ \\
\hline & & Investment & $\begin{array}{l}\text { Willingness } \\
\text { to invest }\end{array}$ & $\begin{array}{l}\text { a. you do not really understand, if there is } \\
\text { excess money, just save } \\
\text { b. you will choose which one will give the } \\
\text { best return } \\
\text { c. you will not invest to which contain Riba', } \\
\text { you will choose real investment, metal or } \\
\text { sharia. } \\
\text { d. you will avoid riba, but there's a possibility } \\
\text { to invest in public institution without } \\
\text { Islamic label as long the business practical } \\
\text { relevant to the sharia value. }\end{array}$ & $\begin{array}{l}\text { Interval } \\
\text { scale }\end{array}$ \\
\hline & & $\begin{array}{l}\text { Financing } \\
\text { or credit }\end{array}$ & $\begin{array}{l}\text { Considerati } \\
\text { on to } \\
\text { choose a } \\
\text { company in } \\
\text { financing } \\
\text { or credit }\end{array}$ & $\begin{array}{l}\text { a. any company who provide financing for } \\
\text { you. } \\
\text { b. you will learn the cost will you spend for } \\
\text { credit } \\
\text { c. you will choose credit facility from sharia } \\
\text { institution, although the margin is higher } \\
\text { than the interest. } \\
\text { d. still considering non-sharia institution, } \\
\text { because not all financing non-sharia } \\
\text { institution not accordance with sharia } \\
\text { value. }\end{array}$ & $\begin{array}{l}\text { Interval } \\
\text { scale }\end{array}$ \\
\hline
\end{tabular}

\subsubsection{Planned Behavior}

It is a factor that is used to distinguish the consumer making decision in choosing a credit facility of conventional property or finance sharia property by using the theory of planned behavior (Theory of Planned Behavior) approach where the customer interest is influenced by three main factors, they are:

\subsubsection{Attitude toward behavior (attitude toward behavior)}

It is the respondent's trust of the finance sharia mortgage objective. There are three indicators were developed based on the functions of attitudes, they are: religiosity, economic and service quality. 


\subsubsection{Subjective norms (subjective norms)}

It is the third party influence or external influence on the respondent's behavior regarding their objective towards finance sharia property. There are five indicators which are developed, they are: the influence of the husband or wife, the influence of parents or close relatives, friends influence, taklim friends, friends at work, neighbors, friends in the community setting, influence of religious teachers and the influence of the developer or property agent.

\subsubsection{Perceived behavioral control (perceived behavioral control)}

It is a control that can inhibit or encourage respondents regarding their behavior regarding the objective towards finance sharia property. There are three indicators are developed based on the functions of attitudes, they are: religiosity, economic and service quality.

Table 4. Indicator and parameter planned behavior variable

\begin{tabular}{|c|c|c|c|c|c|c|}
\hline Variable & Variable description & Dimension & Indicator & & Questionnaires grating & $\begin{array}{l}\text { Measurement } \\
\text { scale }\end{array}$ \\
\hline \multirow[t]{12}{*}{$\begin{array}{l}\text { Planned } \\
\text { behavior }\end{array}$} & $\begin{array}{l}\text { The attitude model } \\
\text { predicted consumer } \\
\text { interest and intention } \\
\text { to perform behavior } \\
\text { or action. }\end{array}$ & $\begin{array}{l}\text { Attitude toward } \\
\text { behavior } \\
\text { (attitude toward } \\
\text { behavior) }\end{array}$ & Religiosity & a. & $\begin{array}{l}\text { Choosing financing sharia } \\
\text { property as one of action to } \\
\text { implement the religion value. }\end{array}$ & Interval scale \\
\hline & & & & & $\begin{array}{l}\text { Choosing financing sharia } \\
\text { property to avoid riba } \\
\text { (interest). }\end{array}$ & \\
\hline & & & Economic & c. & $\begin{array}{l}\text { Choosing financing sharia } \\
\text { property to avoid rate } \\
\text { interest fluctuation credit in } \\
\text { the future. }\end{array}$ & \\
\hline & & $\begin{array}{l}\text { Subjective } \\
\text { norms } \\
\text { (subjective } \\
\text { norms) }\end{array}$ & $\begin{array}{l}\text { Husband/wife } \\
\text { recommendation }\end{array}$ & A. & $\begin{array}{l}\text { your wife or husband have } \\
\text { ever advised you to use } \\
\text { financing sharia property in } \\
\text { property purchasing. }\end{array}$ & Interval scale \\
\hline & & & $\begin{array}{l}\text { Parents/relatives } \\
\text { recommendation }\end{array}$ & B. & $\begin{array}{l}\text { parents/closed relatives have } \\
\text { ever advised you to use } \\
\text { financing sharia property in } \\
\text { property purchasing. }\end{array}$ & \\
\hline & & & $\begin{array}{l}\text { Community } \\
\text { recommendation }\end{array}$ & $\mathrm{C}$ & $\begin{array}{l}\text { community religion / majelis } \\
\text { taklim / office friend / } \\
\text { neighbors / community } \\
\text { friend have ever advised you } \\
\text { to use financing sharia } \\
\text { property in property } \\
\text { purchasing. }\end{array}$ & \\
\hline & & & $\begin{array}{l}\text { Religion } \\
\text { teacher/leader } \\
\text { recommendation }\end{array}$ & d. & $\begin{array}{l}\text { Religion teacher/leader has } \\
\text { ever advised you to purchase } \\
\text { property through sharia } \\
\text { financing. }\end{array}$ & \\
\hline & & & $\begin{array}{l}\text { Developer / } \\
\text { property agent } \\
\text { recommendation }\end{array}$ & e. & $\begin{array}{l}\text { Marketing developer } \\
\text { property agent have ever } \\
\text { advised to purchase property } \\
\text { through sharia financing. }\end{array}$ & \\
\hline & & Perceived & Economic & a. & Adequacy income & Interval scale \\
\hline & & $\begin{array}{l}\text { behavioral } \\
\text { control }\end{array}$ & & & $\begin{array}{l}\text { Interest rate / margin } \\
\text { financing }\end{array}$ & \\
\hline & & (perceived & & c. & Mortgage cost & \\
\hline & & $\begin{array}{l}\text { behavioral } \\
\text { control) }\end{array}$ & Quality service & $\begin{array}{l}\text { a. } \\
\text { b. }\end{array}$ & $\begin{array}{l}\text { Speed } \\
\text { Easiness }\end{array}$ & \\
\hline
\end{tabular}




\subsection{Data processing and analysis technique}

In this study, some data analysis has been carried out with the following explanation:

Group Analysis (Cluster)

Cluster analysis procedures performed in this study used cross-tabulation. This classification was done based on respondents' answers to the questionnaires. Cluster analysis is expected to explain the consumer segmentation in the use of financing services sharia property and conventional credit property.

Multiple Regression Analysis

Multiple linear regression analysis (multiple regression analysis) is a statistical technique that can be used to analyze the relationship between a single dependent variable and several independent variables. Multiple linear regression formula is as follows:

$\mathrm{Y}=\beta_{0}+\beta_{1} \mathrm{X}_{1}+\beta_{2} \mathrm{X}_{2}+\beta_{3} \mathrm{X}_{3}+\beta_{4} \mathrm{X}_{4}+\beta_{5} \mathrm{X}_{5}+\beta_{6} \mathrm{X}_{6}$

Where;

$\mathrm{Y} \quad$ : proposing financing sharia mortgage interest

$\beta_{0} \quad:$ Constant coefficient

$\beta_{1}, \beta_{2}, \beta_{6} \quad$ : Regression coefficient

$\mathrm{X}_{1} \quad$ : Behavior beliefs

$\mathrm{X}_{2} \quad$ : Output evaluation

$\mathrm{X}_{3} \quad$ : Normative beliefs

$\mathrm{X}_{4} \quad$ : Comply motivation

$\mathrm{X}_{5} \quad$ : Control beliefs

$\mathrm{X}_{6} \quad$ : Control power factor

In the multiple linear regression analysis, it conducted a T-test to prove the influence hypothesis individually from the independent variables on the dependent variable. If the significance value of the $t$ test is less than 0.05 , it means that the independent variables significantly influenced the dependent variable partially. On the contrary, if the significance value of the $t$ tests was more than 0.05 , then the independent variable has no significant effect on the dependent variable partially.

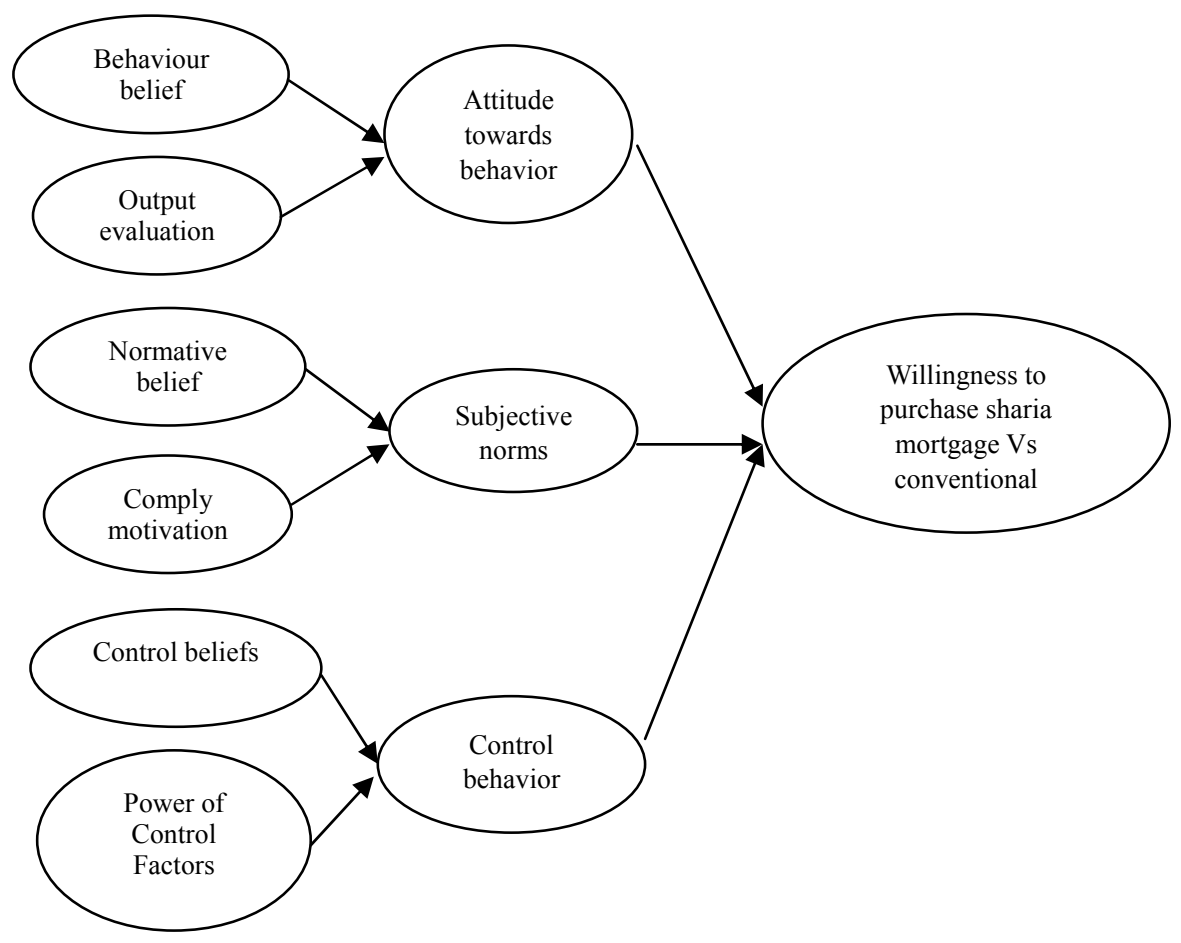

Picture 1. Conceptual Framework 


\section{Result and Discussions}

\subsection{Sharia Consumer Mortgage Cluster analysis}

Once the cluster is formed, then the distribution of the number of objects (respondents) for each cluster can be seen in Table 4.

Table 4. Cross tabulation of applying conventional credit property and sharia next six months

\begin{tabular}{|c|c|c|c|c|c|}
\hline & & & \multicolumn{2}{|c|}{$\begin{array}{l}\text { Applying conventional credit property next six } \\
\text { months }\end{array}$} & \multirow[t]{2}{*}{ Total } \\
\hline & & & Disagree & Agree & \\
\hline \multirow{4}{*}{$\begin{array}{l}\text { Applying financing sharia property } \\
\text { next six months }\end{array}$} & \multirow{2}{*}{ Disagree } & Total & 45 & 16 & 61 \\
\hline & & $\%$ & $73.8 \%$ & $26.2 \%$ & $100.0 \%$ \\
\hline & \multirow{2}{*}{ Agree } & Total & 6 & 83 & 89 \\
\hline & & $\%$ & $6.7 \%$ & $93.3 \%$ & $100.0 \%$ \\
\hline \multirow{2}{*}{ Total } & & Total & 51 & 99 & 150 \\
\hline & & $\%$ & $34.0 \%$ & $66.0 \%$ & $100.0 \%$ \\
\hline
\end{tabular}

Based on Table 4, it shows that from the 61 respondents who did not agree to apply for a sharia mortgage in the next six months were 45 respondents did not propose a conventional mortgage and 16 respondents who would apply a conventional mortgage. The respondent majority were as many as 83 respondents will apply for financing/sharia mortgage or conventional properties simultaneously in the next six months. This shows that the majority of respondents who have a preference for both conventional and sharia based mortgage products.

At the same time, the respondents were asked questions in more depth about their interest in proposing Sharia mortgage although the cost is more expensive and the procedure longer than a conventional mortgage. The results can be seen in Table 5 .

Table 5. Cross tabulation in applying conventional credit property and sharia although the cost more expensive and the procedure is longer

\begin{tabular}{|c|c|c|c|c|c|}
\hline & & & \multicolumn{2}{|c|}{$\begin{array}{l}\text { Applying conventional credit property next six } \\
\text { month }\end{array}$} & \multirow[t]{2}{*}{ Total } \\
\hline & & & Disagree & Agree & \\
\hline \multirow{4}{*}{$\begin{array}{l}\text { Apply financing sharia property } \\
\text { although the cost is more expensive } \\
\text { and the procedure is longer }\end{array}$} & \multirow{2}{*}{ Disagree } & Total & 45 & 19 & 64 \\
\hline & & $\%$ & $70.3 \%$ & $29.7 \%$ & $100.0 \%$ \\
\hline & \multirow{2}{*}{ Agree } & Total & 6 & 80 & 86 \\
\hline & & $\%$ & $6.7 \%$ & $93.3 \%$ & $100.0 \%$ \\
\hline \multirow{2}{*}{ Total } & & Total & 51 & 99 & 150 \\
\hline & & $\%$ & $34.0 \%$ & $66.0 \%$ & $100.0 \%$ \\
\hline
\end{tabular}

Based on Table 5, it shows three respondents had cancelled their interest to apply for a sharia mortgage if the cost was more expensive and the procedure was longer than conventional credit property. While the majority of respondents were still applying even though financing sharia mortgage is more expensive and has a longer procedure than conventional credit property. These results indicate that the majority of respondents were loyal to sharia based financing products which do not negate the possibility that the respondent can also apply for a conventional credit property in the next six months.

The next stage is a profiling cluster in order to describe each cluster characteristics based on psychographic lifestyles and personalities which can be seen in Table 6 .

Table 6. Psychographic lifestyle and personality Profiling cluster apply conventional credit property next six months

\begin{tabular}{cccc}
\hline $\begin{array}{c}\text { Respondent's } \\
\text { characteristics }\end{array}$ & Cluster 1 & Cluster 2 & Cluster 3 \\
\hline Age: & & & $7.5 \%$ \\
$\leq 30$ years & - & - & $50.0 \%$ \\
$31-35$ years & $33.3 \%$ & $52.6 \%$ & $15.0 \%$ \\
$36-40$ years & $33.3 \%$ & $21.1 \%$ & \\
\hline
\end{tabular}




\begin{tabular}{|c|c|c|c|}
\hline $\begin{array}{l}\text { Respondent's } \\
\text { characteristics }\end{array}$ & Cluster 1 & Cluster 2 & Cluster 3 \\
\hline $41-45$ years & $33.3 \%$ & $21.1 \%$ & $25.0 \%$ \\
\hline$\geq 46$ years & - & $5.3 \%$ & $2.5 \%$ \\
\hline \multicolumn{4}{|l|}{$\begin{array}{l}\text { Total family } \\
\text { members: }\end{array}$} \\
\hline $1-2$ peoples & - & $5.3 \%$ & $17.5 \%$ \\
\hline $3-4$ peoples & $50.0 \%$ & $26.3 \%$ & $36.3 \%$ \\
\hline $5-6$ peoples & $16.7 \%$ & $42.1 \%$ & $35.0 \%$ \\
\hline$\geq 7$ peoples & $33.3 \%$ & $2.3 \%$ & $11.3 \%$ \\
\hline \multicolumn{4}{|l|}{ Gender: } \\
\hline Male & $50.0 \%$ & $57.9 \%$ & $65.0 \%$ \\
\hline Female & $50.0 \%$ & $42.1 \%$ & $35.0 \%$ \\
\hline \multicolumn{4}{|l|}{$\begin{array}{l}\text { Average food } \\
\text { expenditure per } \\
\text { months: }\end{array}$} \\
\hline$<\operatorname{Rp} 2$ million & $16.7 \%$ & $52.6 \%$ & $23.8 \%$ \\
\hline $\begin{array}{l}\mathrm{Rp} 2 \text { million }-\mathrm{Rp} \\
3 \text { million }\end{array}$ & $83.3 \%$ & $47.4 \%$ & $65.0 \%$ \\
\hline$>$ Rp 3 million & - & - & $11.3 \%$ \\
\hline \multicolumn{4}{|l|}{$\begin{array}{l}\text { Average non-food } \\
\text { expenditure per } \\
\text { month: }\end{array}$} \\
\hline$<\operatorname{Rp} 2$ million & $66.7 \%$ & $42.1 \%$ & $48.8 \%$ \\
\hline $\begin{array}{l}\text { Rp } 2 \text { million - Rp } \\
3 \text { million }\end{array}$ & - & $52.6 \%$ & $43.8 \%$ \\
\hline $\begin{array}{l}\text { > Rp } 3 \text { million } \\
\text { Occupation: }\end{array}$ & $33.3 \%$ & $5.3 \%$ & $7.5 \%$ \\
\hline Civil servants & $16.7 \%$ & $52.6 \%$ & $25.0 \%$ \\
\hline Private employee & $50.0 \%$ & $47.4 \%$ & $60.0 \%$ \\
\hline Entrepreneur & $16.7 \%$ & - & $11.3 \%$ \\
\hline Others & $16.7 \%$ & - & $3.8 \%$ \\
\hline \multicolumn{4}{|l|}{ Education: } \\
\hline Diploma & - & $10.5 \%$ & $8.8 \%$ \\
\hline S1 & $83.3 \%$ & $68.4 \%$ & $61.3 \%$ \\
\hline S2 & $16.7 \%$ & - & $17.5 \%$ \\
\hline S3 & - & $21.1 \%$ & $12.5 \%$ \\
\hline \multicolumn{4}{|l|}{ Religion } \\
\hline Moslem & $83.3 \%$ & $73.7 \%$ & $65.0 \%$ \\
\hline Catholic & - & $5.3 \%$ & $7.5 \%$ \\
\hline Protestant & $16.7 \%$ & $10.5 \%$ & $22.5 \%$ \\
\hline Hinduism & - & $10.5 \%$ & $5.0 \%$ \\
\hline \multicolumn{4}{|l|}{ Marital status } \\
\hline Single & - & - & $5.0 \%$ \\
\hline Married & $83.3 \%$ & $84.2 \%$ & $88.8 \%$ \\
\hline Widow / widower & $16.7 \%$ & $15.8 \%$ & $6.3 \%$ \\
\hline Activity & $\begin{array}{c}\text { Monotone, practical, introvert, and } \\
\text { decision marker }\end{array}$ & $\begin{array}{c}\text { Dynamic, practical, extrovert, and } \\
\text { decision marker }\end{array}$ & $\begin{array}{c}\text { Dynamic, practical, extrovert, and } \\
\text { decision marker }\end{array}$ \\
\hline Willingness & $\begin{array}{l}\text { Did not want to attract from others, } \\
\text { conservative, consider religious } \\
\text { values when applying for mortgage, } \\
\text { tended to like stable mortgage rate } \\
\text { interest and considered others } \\
\text { opinions }\end{array}$ & $\begin{array}{l}\text { Want to be others attention, risk } \\
\text { taker, unconsidered religion value } \\
\text { in apply mortgage, tend to like } \\
\text { progressive mortgage rate interest } \\
\text { and considered others opinions }\end{array}$ & $\begin{array}{l}\text { Want to be others attention, risk } \\
\text { taker, unconsidered religion value in } \\
\text { apply mortgage, tend to like stable } \\
\text { mortgage rate interest and considered } \\
\text { others opinions }\end{array}$ \\
\hline Opinion & $\begin{array}{c}\text { Tended to like house with LT } 36-70 \\
\text { type, willing to take financing bank } \\
\text { and assume that sharia mortgage is the } \\
\text { best choice }\end{array}$ & $\begin{array}{c}\text { Tend to like house with LT }>70 \mathrm{~m} 2 \\
\text { type, willing to take credit Bank } \\
\text { financing and assume that } \\
\text { conventional mortgage is the best } \\
\text { choice }\end{array}$ & $\begin{array}{l}\text { Tend to like house with LT } 36-70 \\
\text { type, willing to take credit/financing } \\
\text { Bank and assume that sharia } \\
\text { mortgage is the best choice }\end{array}$ \\
\hline $\begin{array}{l}\text { Psychographic } \\
\text { personality }\end{array}$ & Conformist & Rationalist & Universalist \\
\hline $\mathrm{N}$ & 6 & 19 & 80 \\
\hline
\end{tabular}




\subsection{Multiple Linear Regression Analysis The Factors That Influence Consumer in Choosing Sharia Mortgage}

Multiple linear regression analysis is used to analyze the relationships between independent variable consisting of trust behavior, output evaluation, normative beliefs, comply motivations, trust management, and power control factors towards the customer's interest to apply for a sharia mortgage; such are presented in Table 7.

Table 7. Attitude toward behavior on customer interest to apply sharia mortgage

\begin{tabular}{cccc}
\hline & Regression coefficient & t-count & Significant \\
\hline Constanta & 1.826 & 2.285 & 0.024 \\
Behavior beliefs $\left(\mathrm{X}_{1}\right)$ & -0.087 & -0.646 & 0.520 \\
Output evaluation $\left(\mathrm{X}_{2}\right)$ & 0.335 & 2.130 & 0.035 \\
Normative belief $\left(\mathrm{X}_{3}\right)$ & -0.037 & -0.402 & 0.689 \\
Comply motivation $\left(\mathrm{X}_{4}\right)$ & -0.044 & -0.331 & 0.742 \\
Control beliefs $\left(\mathrm{X}_{5}\right)$ & 0.042 & 0.211 & 0.834 \\
Power control factor $\left(\mathrm{X}_{6}\right)$ & 0.221 & 1.443 & 0.152 \\
\hline
\end{tabular}

Based on Table 7, it shows that behavior belief factor (X1), output evaluation(X2), normative belief (X3), comply motivation (X4), control belief (X5) and control power factor (X6) influence simultaneously on the customer's interest to apply for financing sharia property.

However, if it views partially that only output evaluation factor (X2) which indicates a significant $(0,035)$ influence that the customer interest to apply for financing sharia property. Variables factors can be explained through picture 2 .
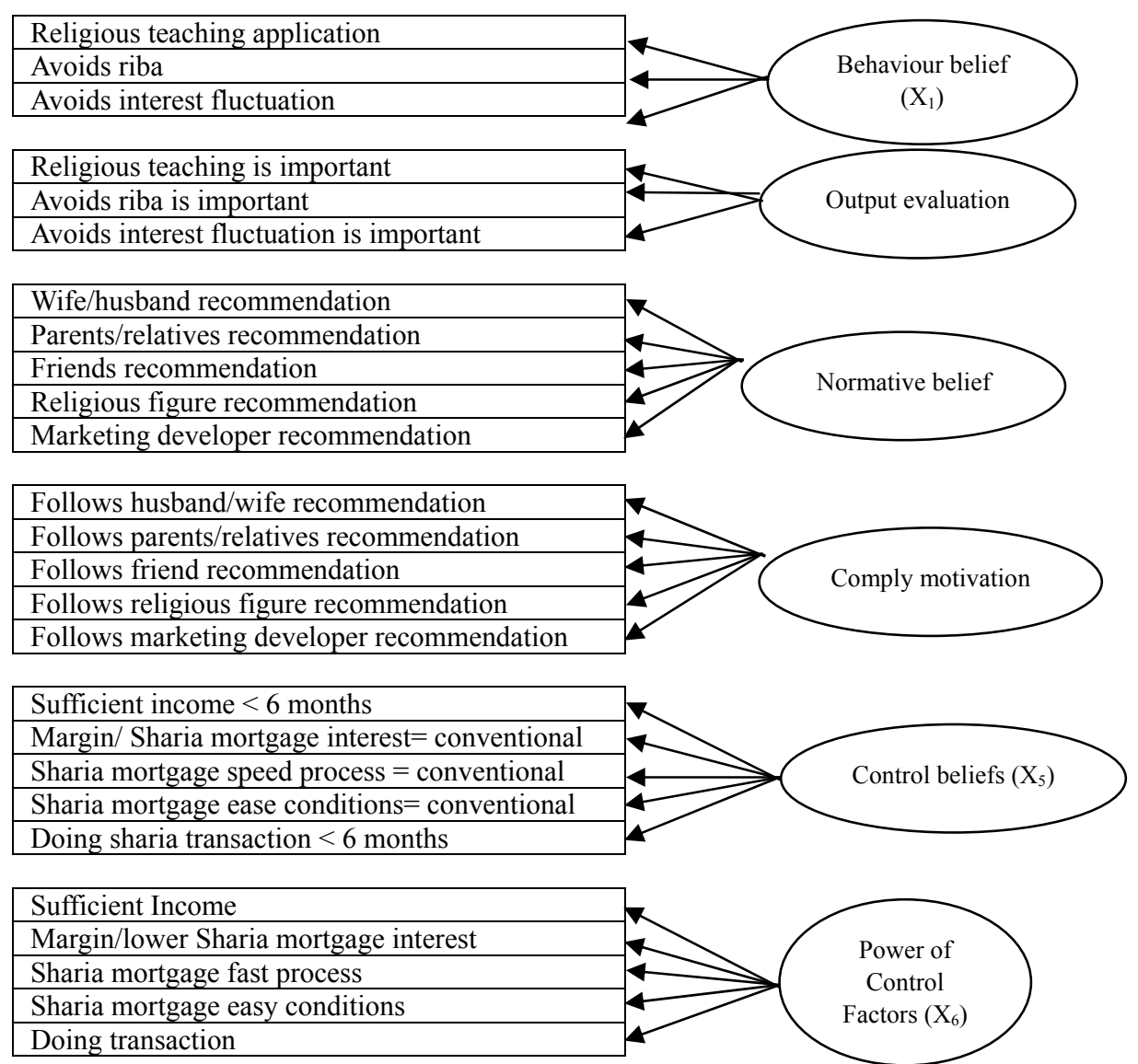

Picture 2. Variable Factors 
Based on picture 2, Factors output evaluation (X2) consists of variables and the application of religion is important, the avoidance of interest is important, and the avoidance of fluctuations in interest rates are important. This indicates that consumers were aware about the implementation of religious values in the selection of sharia mortgage products.

This is in line with the research conducted by Rivai et al. (2010). The factors that influenced consumers to choose the banking industry are perception / the belief that bank interest contrary with confidence / religious. In addition, Amin et al. (2013) in research behavioral therapy pertaining to Muslim consumers (empirical studies behavior consumers sharia mortgage in Malaysia) explained that factors pertaining to education and religious satisfaction were factors that determined preference of consumers in taking a Sharia mortgage.

Amri (2012) conducted research analysis factors which affected customers in the selection of a product in the mortgage loan industry: a case study at Bank Muamalat Indonesia that religion became the primary reason for the Muamalat customers in using a Sharia mortgage. Five the top factors were the dominant choice for customers; namely, (1) customers are aware of practices which are forbidden, (2) customers consider syariah principle when choosing a mortgage loan, (3) if customers when pay off their loan quicker they are not penalized, (4) Bank Muamalat mortgage loan is in accordance with the syariah principle, (5) if payment is delayed or behind the penalty is relatively small.

Meanwhile, the behavior belief factor (X1), normative belief (X3), comply motivation (X4), control belief (X5) and control power factor (X6) did not significantly affect the customer's interest to apply for financing sharia property.

\subsection{Managerial Implication}

Based on the results, it showed that most of the respondents on $3^{\text {rd }}$ clusters were interested to apply for conventional and sharia mortgage simultaneously. This shows that the potential of sharia finance is still very significant. Various efforts can be implemented to optimize the sharia mortgage through marketing strategies that can be seen in Table 8 .

Table 8. Managerial implication

\begin{tabular}{ll}
\hline Marketing Strategies & Managerial implication \\
\hline Generic strategies & $\begin{array}{l}\text { Applies differentiation strategies to products, services, person / an employee of a bank, distribution or } \\
\text { image of sharia mortgage on the market mass so sharia mortgage is unique compared with conventional } \\
\text { property credit. }\end{array}$ \\
\hline Market challengers strategies & Applies by implementing attack strategies which are enacted by an indirect attack by taking a shortcut \\
\hline $\begin{array}{l}\text { Marketing mix strategies } \\
\text { Product }\end{array}$ & $\begin{array}{l}\text { Applies expansion of product lines thourgh rapid technology change in various sectors which will } \\
\text { encourage sharia banks to renew their products line. }\end{array}$ \\
Price & $\begin{array}{l}\text { Applies prices based on the competition (going rate pricing) where margins of sharia mortgages are set } \\
\text { based on the indirect consideration benchmark conventional mortgage as used by their competitors. }\end{array}$ \\
- & $\begin{array}{l}\text { Applies an agressive strategy through increasing the number of alliance cooperations with property } \\
\text { property developers / agents to sell a sharia mortgage with a given incentive. } \\
\text { Cooperate with high-tech companies such as Telkom, Facebook, Twitter or Instagram and advertise } \\
\text { sharia mortgages with a marketing target that is more specific. }\end{array}$ \\
\hline
\end{tabular}

\section{Conclusions and Suggestions}

\subsection{Conclusions}

Based on the analysis above, the research can conclude that the mortgage market segments are divided by three clusters which are: a) First cluster, as many as six respondents or $6.7 \%$ of the total respondents interested in buying home just using a sharia mortgage. b) Second cluster, as many as 19 respondents or $29,7 \%$ of the total respondents were interested in buying a home just using conventional mortgage. c) Third cluster, as many as 80 respondents or $93.3 \%$ of the total respondents were interested in buying a home using both conventional and syariah mortgages.

Factors evaluation output $\left(\mathrm{X}_{2}\right)$ in the form of the interests of the application of religion, avoid usury and fluctuations of factors, suggests a significant impact on the interest in a proposed sharia mortgage.

In terms of managerial implications, in order to increase the sharia mortgage market share a strategy can be leveraged to approach both the community and socialization through social media as an effort to provide 
information to the public regarding the competitive advantage of owning a property by syariah financing. Moreover, support or an authority figure is required from the religion of Islam to further convince and rally the community to be more pro-syariah financing.

\subsection{Suggestions}

The suggestions which are submitted and related to this study are:

1. The management of Sharia banks should focus more on marketing sharia mortgages and continue to improve both socialization and promotions to leverage forward the concept of the implementation of religious teaching, the prohibition of riba and avoidance of interest fluctuations in the long term; such as a major differentiator to conventional credit property. Moreover, Sharia banks should also be able to provide an excellent service in the form of a rapid process procedure, easing of compliance conditions and the provision of a competitive financing margin/interest rate. These factors proved that the majority of respondents are interested to choose a sharia mortgage as opposed to a more conventional mortgage.

2. Future researchers can conduct similar studies using different techniques, for example, by conducting direct interviews with respondents using open-ended questions which allow the sampled respondents to offer opinions based on personal viewpoints and experiences; such can allow theoretical concepts to be translated into practical applications and interventions within the Indonesian banking system.

\section{References}

Ajzen, I. (2005). Attitudes, Personality and Behavior. New York (US): Open University Press.

Ali, S. (2013). Prediksi perilaku ramah lingkungan yang dipengaruhi oleh nilai dan gaya hidup konsumen. Jurnal Perspektif Bisnis, 1(1), 112-125.

Amalia, S., \& Nurmalina, R. (2011). Analisis Perilaku Debitur Dalam Proses Keputusan Pembelian MORTGAGE di Wilayah Bogor Untuk Pengembangan Produk MORTGAGE iB. [thesis]. Bogor (ID): Institut Pertanian Bogor.

Ambiatini, Kirbrandoko, \& Sanim, B. (2005). Analisis Strategi Pemasaran Produk MORTGAGE Bank X. [tesis]. Bogor (ID): Institut Pertanian Bogor.

Amin, H., Abdul Rahman, A. R., \& Razak, D. A. Consumer Acceptance of Islamic Home Financing. International Journal of Housing Markets and Analysis, 7(3), 307-332. https://doi.org/10.1108/IJHMA-12-2012-0063.

Amin, H., Abdul Rahman, A. R., \& Razak, D. A. Theory of Islamic Consumer Behaviour An Empirical Study of Consumer Behaviour Of Islamic Mortgage In Malaysia. Journal of Islamic Marketing, 5(2), 273-301. https://doi.org/10.1108/JIMA-06-2013-0042

Amri, K. F. (2012). Analisis faktor-faktor yang mempengaruhi nasabah dalam pemilihan KPR: studi kasus Bank Muamalat Indonesia, Tbk. [skripsi]. Jakarta (ID): Universitas Indonesia.

Antonio, M. S. (2001). Bank Syariah Teori dan Praktek. Jakarta (ID): Gema Insani Press.

Bank Indonesia. (2015). Surat Edaran Bank Indonesia nomor 17/10/PBI/2015 tentang Rasio 'Loan To Value atau Rasio Financing To Value' untuk kredit atau pembiayaan properti dan uang muka untuk kredit atau pembiayaan kendaraan bermotor. Jakarta (ID): Bank Indonesia.

Blue, C. L. (1995). The predictive capacity of the theory reasoned action and the theory of planed behavior in exercise study: an integrated literature review. Study in Nursing and Health, 18, 105-121.

[BPS] Badan Pusat Statistik Provinsi Jawa Timur. (2016). Berita Resmi Statistik No. 12/02/35/Th.XIV tanggal 05 Februari 2016 tentang Pertumbuhan Ekonomi Jawa Timur Tahun 2015. Surabaya: Badan Pusat Statistik.

Daud, D. (2013). Promosi dan Kualitas Layanan Pengaruhnya Terhadap Keputusan Konsumen Menggunakan Jasa Pembiayaan Pada PT. Bess Finance Manado. Jurnal Emba, 1(4), 51-59.

Djaja, S., Yuniarinto, A., \& Suman, A. (2010). Analisis pengaruh perilaku konsumen dalam pengambilan keputusan: studi pembelian rumah sangat sederhana tipe 36 melalui KPR BTN di kota administrasi Jember. Jurnal Wacana, 13(1), 58-69.

Djamaludin, M. D., Ujang, S., \& Gustia Nur Aria M. (2009). Analisis Kepuasan Dan Loyalitas Konsumen Jamu Gendong Di Kota Sukabumi. Jurnal Ilmu Keluarga dan Konsumen, 2(2), 174-184. Departemen Ilmu Keluarga dan Konsumen, Fakultas Ekologi Manusia, Institut Pertanian Bogor (ID).

Ekasari, N. (2014). Pengaruh promosi berbasis sosial media terhadap keputusan pembelian produk jasa 
pembiayaan kendaraan pada PT.BFI Finance Jambi. Jurnal Penelitian Universitas Jambi Seri Humaniora, 16(2), 81-102.

Elfinur, R. S. (2015). Analisis segmentasi pasar berdasarkan demografis dan perilaku didasarkan manfaat pada nasabah kredit BPR Mitra Rakyat Riau Pekanbaru. Jurnal Tepak Manajemen Bisnis, 7(1), 18-31.

Fuad, H. (2016). BRISharia genjot konsumer KPR menengah ke bawah. [internet]. [diunduh: 2016 Juli 05]. Tersedia pada: http://ekbis.sindonews.com.

Furaiji, F., Latuszynska, M., \& Wawrzyniak, A. (2012). An Empirical Study of the Factors Influencing Consumer Behaviour in the Electric Appliances Market. Journal of Contemporary Economics, 6(3), 76-86. https://doi.org/10.5709/ce.1897-9254.52

Hasanuddin, R., \& Musfar, T. F. (2015). Analisis pengaruh segmentasi gaya hidup terhadap keputusan penggunaan dan kepuasan konsumen jasa simply fresh laundry di kota Pekanbaru. Jurnal Online Mahasiswa (JOM) Bidang Ilmu Ekonomi, 1(2), 1-15.

Ismail, S., Azmi, F., \& Thurasamy, R. (2014). Selection criteria for islamic home financing in Malaysia. International Journal of Business and Society, 15(1), 97-110.

Irviana, K., Nurmalina, R., \& Suroso, A. I. (2008). Analisis segmen pasar dan perilaku nasabah terhadap bank sharia di wilayah DKI Jakarta. [tesis]. Bogor (ID): Institut Pertanian Bogor.

Iswantoro, C., \& Anastasia, N. (2013). Hubungan demografi, anggota keluarga dan situasi dalam pengambilan keputusan pendanaan pembelian rumah tinggal di Surabaya. Finesta Journal of Finance, 1(2), 125-129.

Kartika, E. (2008). Analisis faktor eksternal yang mempengaruhi keputusan membeli mobil Toyota Avanza dan Daihatsu Xenia Medan. [tesis]. Medan (ID): Universitas Sumatera Utara.

[Kemendagri RI] Kementerian Dalam Negeri Republik Indonesia. (2014). Rekapitulasi data kependudukan per provinsi (edisi 31 Desember 2013). [internet]. [diunduh: 2016 Agustus 23]. Tersedia pada: http://www.dukcapil.kemendagri.go.id.

Kennedy, B. P. (2013). The Theory of Planned Behavior And Financial Literacy: A Predictive Model For Credit Card Debt. [Disertasi]. Huntington (USA): Marshall University.

Krisnawati, Y., Kirbrandoko, \& Djamaludin, M. D. (2008). Analisis persepsi developer terhadap produk Kredit Pemilikan Rumah (KPR) bank XYZ cabang Bogor. [tesis]. Bogor (ID): Institut Pertanian Bogor.

Kunto, Y. S., \& Pasla, P. R. (2006). Segmentasi gaya hidup pada mahasiswa program studi pemasaran Universitas Kristen Petra. Jurnal Manajemen Pemasaran, 1(1), 13-21.

Kustrihariyanto, V. (2008). Pemanfaatan Kredit Pemilikan Rumah (KPR) (studi deskriptif kualitatif tentang pengetahuan dan perilaku nasabah dalam pemanfaatan kredit pemilikan rumah di Bank BTN Surakarta). [skripsi]. Surakarta (ID): Universitas Sebelas Maret.

Lalitamanik, R., Apriatni, \& Dewi R. S. (2014). Pengaruh activity, interest, opinion (AIO) dan persepsi harga terhadap keputusan menonton film di bioskop E-Plaza Semarang. Diponegoro Journal of Social and Political Science, 1(1), 1-10.

Lestari, S. (2008). Analisis perilaku konsumen dalam pembelian sepeda motor Yamaha Mio di kota Surakarta. [tesis]. Surakarta (ID): Universitas Sebelas Maret Surakarta.

Listyorini, S. (2012). Analisis faktor-faktor gaya hidup dan pengaruhnya terhadap pembelian rumah sehat sederhana (Studi pada pelanggan perumahan Puri Dinar Mas PT.Ajisaka di Semarang). Jurnal Administrasi Bisnis, 1(1), 12-24.

Maharani, R. M. (2009). Analisis hubungan capital adequacy ratio loan to deposit ratio, non performing loan, net interest margin dan biaya operasional dengan pendapatan operasional terhadap profitabilitas bank umum yang listing di bursa efek Indonesia periode 2003 - 2007. [skripsi]. Depok: Universitas Indonesia.

Marwa, S., Ujang, S., \& Rita, N. Bauran Pemasaran Memengaruhi Keputusan Konsumen Dalam Pembelian Asuransi Jiwa Individu. Jurnal Ilmu Keluarga dan Konsumen, 7(3), 183-192. Departemen Ilmu Keluarga dan Konsumen, Fakultas Ekologi Manusia, Institut Pertanian Bogor (ID)..

Mikhriani, M. (2012). Analisis segmentasi pasar perawatan kulit wajah Natasha Skin Care Yogyakarta. Jurnal Dakwah, 13(1), 105-136.

Mukhson, M. A., Magdalena, M., \& Budi, L. (2016). Factors affecting the decision to take credit customers future program package (pmd) in Bank BTPN Sharia (case study at the state saving bank sharia Pamularsih 
KCS). Journal of Management, 2(2), 1-13.

Nuary, F. D. (2010). Implementasi Theory of Planned Behavior dalam adopsi e-commerce oleh UKM (studi pada UKM yang berada di Kota Surakarta tahun 2009). [skripsi]. Surakarta (ID): Universitas Sebelas Maret.

Nugroho, T., Ujang, S., \& Kirbandoko. Analisis Faktor-Faktor yang Mempengaruhi Keputusan Pembelian dan Konsumsi Tahu Organik. Indonesian Journal of Business and Entrepreneurship, 1(3), 115-126. https://doi.org/10.17358/IJBE.1.3.115.

[OJK] Otoritas Jasa Keuangan. (2016). Statistika perbankan Indonesia posisi Juni 2016. [internet]. [diunduh: 2016 Agustus 23]. Tersedia pada: http://www.ojk.go.id.

Pratama, I. D., Ujang, S., \& Hari, W. Advertising Avoidance Pada Iklan di Media Televisi. Jurnal Aplikasi Bisnis dan Manajemen, 2(1). Institut Pertanian Bogor (ID). https://doi.org/10.17358/JABM.2.1.1.

Putra, E. C., \& Muhammad, B. S. (2011). Analisis psikografi penonton film Indonesia di Surabaya. Jurnal Insan Media Psikologi, 13(3), 193-202.

Puspita, Y., \& Untarini, N. (2014). Analisis perbedaan gaya hidup dan pengaruhnya terhadap keputusan pembelian sepatu olahraga merek Adidas di Surabaya. Jurnal Mahasiswa Teknologi Pendidikan, 2(4), 1503-1514.

Radiah, D. S. (2014). Analisis faktor-faktor yang mempengaruhi keputusan nasabah mengambil MORTGAGE pada Bank Mandiri cabang utama Samarinda. eJournal Ilmu Administrasi Bisnis Universitas Mulawarman, 2(1), 15-29.

Ramdhana, V. (2010). Analisis strategi pemasaran produk CMM (Consumer Mass Market) pada Bank Danamon Indonesia cabang Margonda Depok. [skripsi]. Bogor (ID): Institut Pertanian Bogor.

Renzulli A. (2012). Hubungan faktor kredibilitas media terhadap aktivitas akses berita online berdasarkan segmentasi psikografis. [tesis]. Depok (ID): Universitas Indonesia.

Ringim, K. J. (2014). Perception of Negerian Muslim account holders in conventional bank toward Islamic banking products. International Journal of Islamic and Middle Eastern Finance and Management, 7(3), 288-305. https://doi.org/10.1108/IMEFM-04-2013-0045.

Rizal, M. R. (2009). Analisis Perilaku Konsumen dan Pengaruhnya Terhadap Bad Debt Studi Kasus Kartu Kredit Bank X. [tesis]. Bandung (ID): Institut Teknologi Bandung.

Rizal, S. (2013). Potensi dan strategi marketing perbankan sharia pada segmen kelas menengah Indonesia. Al-Iqtishad: Journal of Islamic Economics, 5(2), 181-194. https://doi.org/ 10.15408/aiq.v5i2.2563

Rizki, D. A., Munandar, J. M., \& Andrianto, M. S. (2013). Analisis persepsi konsumen dan strategi pemasaran beras analog (analog rice). Jurnal Manajemen dan Organisasi, 4(2), 144-162.

Rivai, H. A., Lukviarman, S., Lukman, S., \& Masrizal, A. F. (2010). Identifikasi faktor penentu keputusan konsumen dalam memilih jasa perbankan: bank sharia vs bank konvensional. [internet]. [diunduh: 2016 Januari 09]. Tersedia pada: http://www.bi.go.id.

Sanjaya, R., Ujang, S., \& Kirbandoko. (2015). Hubungan Customer Relationship Management dengan Loyalitas Nasabah (Studi Kasus: PT Bank XYZ Cabang Bogor). Jurnal Manajemen Industri Pengembangan Industri Kecil Menengah, 10(2), 151-162.

Salman L. (2010). Analisis perencanaan program komunikasi pemasaran visit Lombok Sumbawa 2012. [tesis]. Surakarta (ID): Universitas Sebelas Maret.

Sari, Y., Ujang, S. M., \& Nadratuzzaman H. Analisis Faktor-Faktor Preferensi Etnis Tionghoa Terhadap Bank Sharia di Indonesia. Jurnal Al Muzara'ah. 3(1).

Sary, Y. (2014). Masuki triwulan III penyaluran kredit di Jatim cenderung melambat. [internet]. [diunduh: 2016 Agustus 22]. Tersedia pada: http://www.rri.co.id.

Sayono, J. A., Ujang, S., \& Noer, A. A. Analisis Faktor-Faktor Yang Mempengaruhi Keputusan Kepemilikan Kartu Kredit (Studi Kasus di Jakarta, Indonesia). Jurnal Organisasi dan Manajemen, 2(2), 67-79. Universitas Tarumanegara (ID).

Siahaan, B. F., Ujang, S., \& Dodik, R. N. (2015). Faktor-Faktor Yang Mempengaruhi Niat Menggunakan Kecap Lokal. Jurnal Ilmu Keluarga dan Konsumen. Departemen Ilmu Keluarga dan Konsumen, Fakultas Ekologi Manusia, Institut Pertanian Bogor (ID), 8(2), 125-132. 
Sumarwan, U. (2011). Riset Pemasaran dan Konsumen Seri 1. Bogor (ID): IPB Press.

Sumarwan, U. Hurriyatun Kabbaro. Analysis of Factors Influencing Credit Card Ownership and Amount of Credit Card Debt. Journal of Wealth Management and Financial Planning, 2.

Sumarwan, U., \& Yurita, M. S. (2012). Persepsi dan Preferensi Iklan Mempengaruhi Niat Beli Anak Pada Produk Makanan Ringan. Jurnal Ilmu Keluarga dan Konsumen. Departemen Ilmu Keluarga dan Konsumen, Fakultas Ekologi Manusia, Institut Pertanian Bogor (ID), 5(2), 185-192.

\section{Copyrights}

Copyright for this article is retained by the author(s), with first publication rights granted to the journal.

This is an open-access article distributed under the terms and conditions of the Creative Commons Attribution license (http://creativecommons.org/licenses/by/4.0/). 